Jurnal Care Vol .5, No.2,Tahun 2017

\title{
PERAN KONSUMSI TEH HIJAU (Camelia sinensis) TERHADAP PENURUNAN INDEKS MASSA TUBUH (IMT) MAHASISWA KEPERAWATAN UNIVERSITAS TRIBHUWANA TUNGGADEWI
}

\author{
Nia Lukita Ariani ${ }^{1}$, Ani Sutriningsih ${ }^{2)}$ \\ ${ }^{1)}$ Universitas Tribhuwana Tunggadewi, Jl. Telaga Warna, Malang, Jawa Timur, Indonesia \\ e-mail: nia.ariani@rocketmail.com
}

\begin{abstract}
Obesity is one of the global health problems with increased morbidity and mortality rate. An alternative therapy that is often studied lately as anti obesity is green tea (Camelia sinensis). This study aimed to determine the effect of consumption of packaged green tea on body mass index (BMI) and waist and hip ratio. The study design was an experimental quasi-design with a total of 33 subjects aged 20-30 years who did not have diabetes mellitus but had BMI $\geq 25 \mathrm{kgm}^{2}$ as case group and BMI $18-22.99 \mathrm{~kg} / \mathrm{m}^{2}$ as control group. Subjects had been required to consume packaged tea for 30 days. The statistical test showed difference of mean of BMI before and after consuming green tea in obese group $(p=0,004)$. The other results showed no significant differences in waist and hip ratio both before and after green tea consumption in obese group $(p=0.916)$ and control group $(p=0.744)$. The relationship between green tea consumption to BMI and waist and hip ratio in both groups was analyzed using Pearson correlation test. The results showed that green tea consumption is not the main determinant of BMI changes and the ratio of waist and hip circumference. This study was unable to control all other determinant variables that influence obesity status.
\end{abstract}

Keyword:body mass index, camelia sinensis,green tea consumption, nursing student

\begin{abstract}
ABSTRAK
Obesitas merupakan salah satu permasalahan kesehatan dengan peningkatan angka morbiditas dan mortalitas. Terapi alternatif yang sering dipelajari dan berfungsi sebagai antiobesitas yaitu teh hijau (Camelia sinensis). Penelitian ini bertujuan untuk menentukan efek konsumsi teh hijau kemasan pada indeks massa tubuh (IMT) dan rasio lingkar pinggang dan panggul. Desain penelitian yaitu kuasi eksperimental dengan total 33 subyek yang berusia 20-30 tahun serta tidak mengalami diabetes mellitus dengan IMT $\geq 25 \mathrm{~kg} / \mathrm{m}^{2}$ sebagai kelompok kontrol dan IMT $18-22.99 \mathrm{~kg} / \mathrm{m}^{2}$ sebagai kelompok kontrol. Subyek diminta untuk mengkonsumsi teh hijau kemasan selama 30 hari. Analisis statistik menunjukkan ada perbedaan rerata IMT sebelum dan sesudah konsumsi teh hijau pada kelompok obesitas $(\mathrm{p}=0,004)$. Hasil lainnya menunjukkan tidak ada perbedaan signifikan pada rasio lingkar pinggang dan panggul sebelum dan sesudah konsumsi teh hijau baik pada kelompok obesitas $(p=0,916)$ dan kelompok kontrol $(p=0,744)$. Hubungan antara konsumsi teh hijau dengan IMT dan rasio lingkar pinggang dan panggul dianalisis menggunakan uji korelasi Pearson. Hasil analisis menunjukkan bahwa konsumsi teh hijau bukan merupakan determinan utama dalam perubahan IMT dan rasio lingkar pinggang dan panggul.
\end{abstract}


Penelitian ini tidak mampu mengontrol faktor determinan lainnya yang mempengaruhi status obesitas.

Kata kunci: konsumsi teh hijau, Camelia sinensis, indeks massa tubuh, mahasiswa keperawatan

\section{PENDAHULUAN}

Obesitas merupakan salah satu permasalahan kesehatan global yang berkaitan dengan peningkatan morbiditas dan angka kematian karena komplikasi lanjutannya berupa diabetes tipe 2, penyakit kardiovaskular, dan kanker (endometrium, payudara, dan kolon) (WHO, 2011). Obesitas menjadi masalah kesehatan bukan hanya di negara maju, melainkan juga di negara berkembang (Ellulu et al., 2014). Bahkan, di negara dengan prevalensi nutrisi kurang masih cukup tinggi seperti beberapa negara di Asia dan Sub-Saharan Afrika. Adanya obesitas menyebabkan permasalahan malnutrisi menjadi dua kali lipat (Roemling \& Qaim, 2012).

Prevalensi obesitas mengalami peningkatan yang signifikan. World Health Organization (WHO) menyebutkan data global dunia individu dewasa yang mengalami berat badan lebih (overweight) sebesar satu milyar dan 300 juta di antaranya mengalami obesitas (WHO, 2011). Ng et al. (2014) juga melaporkan bahwa prevalensi individu berat badan lebih dan obesitas meningkat dalam tiga dekade terakhir secara global. Proporsi jumlah individu dewasa dengan Indeks Massa Tubuh $\left(\right.$ IMT) $\geq 25 \mathrm{~kg} / \mathrm{m}^{2}$ antara tahun 1980- $2013 \quad$ yaitu 28,8\%-36,9\% pada pria, dan dari 29,8\%$38 \%$ pada wanita.

Roemling \& Qaim (2012) melaporkan bahwa pada tahun 1993, 2000, dan 2007, terjadi peningkatan tren obesitas di Indonesia yang signifikan pada individu dewasa yaitu prevalensi wanita lebih tinggi dibanding pria, baik di daerah urban maupun pedesaan. Peningkatan tren di Indonesia dalam jangka waktu tersebut disebabkan oleh beberapa hal antara lain peningkatan pendapatan per kapita, perubahan gaya hidup pasca menikah, ketersediaan bahan pangan, dan perubahan aktivitas fisik. Hasil penelitian tersebut juga menunjukkan bahwa individu yang telah overweight lebih rentan mengalami peningkatan IMT dibandingkan dengan individu yang normal dan hal ini diprediksi akan terus berlangsung dalam beberapa tahun ke depan. Data Riset Kesehatan Dasar (Riskesdas) Indonesia tahun 2013 menunjukkan bahwa prevalensi penduduk laki-laki dewasa (>18 tahun) obesitas pada tahun 2013 
Jurnal Care Vol .5, No.2,Tahun 2017

sebanyak 19,7\%, lebih tinggi dari tahun $2007(13,9 \%)$ dan tahun 2010 (7,8\%) sedangkan prevalensi obesitas perempuan dewasa (>18 tahun) 32,9\%, naik 18,1\% dari tahun $2007(13,9 \%)$ dan 17,5\% dari tahun 2010 (15,5\%). Usaha yang dilakukan untuk menekan prevalensi obesitas, antara lain melalui modifikasi gaya hidup, terapi perilaku, konsumsi obat-obatan, dan operasi dengan berbagai efek samping yang muncul. Hal ini memicu para ahli untuk mencari terapi pengobatan komplementer dan alternatif dalam penurunan berat badan. Salah satu terapi alternatif yang sering diteliti yaitu konsumsi teh hijau (Camelia sinensis), terutama di benua Asia.

Teh merupakan minuman paling banyak kedua dikonsumsi di dunia setelah air, yaitu sekitar dua pertiga dari populasi dunia (Khan \& Mukhtar, 2013). Konsumsi teh mulai menjadi bagian dari gaya hidup masyarakat Indonesia, seiring dengan tingkat pemahaman dan kesadaran tentang gerakan back to nature serta kecenderungan masyarakat mengkonsumsi makanan atau minuman substitusi sebagai imbangan diet kaya lemak, kolesterol, dan rendah serat. Teh hijau merupakan salah satu jenis teh yang prosesnya tidak melalui proses fermentasi. Teh hijau berdasarkan hasil penelitian memiliki kandungan katekin yang merupakan golongan polifenol. Senyawa ini diketahui efektif dalam menurunkan risiko penyakit kardiovaskular, diabetes, penurunan berat badan, sebagai antiinflamasi, antivirus dan antibakteri (Cyboran et al., 2015). Kandungan katekin terbanyak yaitu (-)epigallocatechin-3-gallate (EGCG) ditemukan berkaitan kuat dengan penurunan risiko penyakit metabolik (Sae-tan et al., 2011).

Hasil penelitian in-vivo pada hewan coba menunjukkan bahwa teh hijau berpengaruh terhadap penurunan berat badan dan berat jaringan adiposa. Salah satu mekanisme penurunan berat badan melalui konsumsi teh hijau yaitu dengan meningkatkan absorpsi lipid. Ekstrak teh hijau dan katekin teh hijau juga diketahui meningkatkan konsentrasi lipid feses pada tikus yang diinduksi lemak / tinggi (Sae-tan et al., 2011). Hasil penelitian invitro juga menunjukkan efek anti obesitas melalui mekanisme inhibisi proliferasi dan diferensiasi adiposit serta mengurangi absorpsi lemak dan karbohidrat melalui inhibisi berbagai enzim terkait (Wolfram et al., 2006). Efek anti obesitas teh hijau pada manusia dilaporkan pertama kali pada tahun 2003 dengan subyek penelitian dari Taiwan. Subyek yang mengkonsumsi teh hijau secara rutin lebih dari 10 tahun menunjukkan prosentase lemak tubuh yang lebih 
rendah, lingkar pinggang yang lebih kecil dan penurunan rasio pinggang panggul (Wu et al., 2003).

Berbagai hasil penelitian yang konsisten menunjukkan teh hijau efektif dalam menurunkan berat badan baik secara invitro dan in-vivo pada hewan coba dan manusia, menarik untuk dikaji pada populasi yang lebih luas. Perbedaan etnik, demografi, dan kultur mempengaruhi pola diet masyarakat Indonesia. Selain itu, tubuh juga dapat menunjukkan respon berbeda terhadap zat yang sama sehingga penelitian ini perlu dilakukan untuk mengetahui efektivitas teh hijau sebagai terapi penurunan berat badan khususnya untuk masyarakat daerah Malang.

\section{METODE PENELITIAN}

Desain penelitian ini adalah penelitian kuasi eksperimental. Penelitian dilaksanakan pada bulan Juli-Agustus 2016 kurang lebih selama 30 hari. Seluruh pemeriksaan antropometri dan pemberian perlakuan dilaksanakan di Klinik Ratancha, Universitas Tribhuwana Tunggadewi Malang. Penelitian ini dilakukan atas persetujuan etik yang dikeluarkan oleh Komisi Etik Penelitian Kesehatan Politeknik Kesehatan Kemenkes Malang dengan nomor registrasi 214/ KEPK- POLKESMA/ 2016.
Sampel dalam penelitian yaitu mahasiswa jurusan ilmu keperawatan Fakultas Ilmu Kesehatan Universitas Tribhuwana Tunggadewi Malang sejumlah 33 orang yang terbagi masing-masing ke dalam kelompok obesitas sebanyak 15 orang dan kelompok IMT normal sebanyak 18 orang. Subyek penelitian yang terlibat telah memenuhi kriteria inklusi antara lain laki-laki atau perempuan dengan IMT $\geq$ $25 \mathrm{~kg} / \mathrm{m}^{2}$ (kelompok kasus) dan IMT antara 18,50- 22,99 kg/m² (kelompok kontrol), berusia 20-30 tahun, dan bersedia mengikuti penelitian dengan menandatangani lembar informed consent. Sedangkan kriteria ekslusi meliputi wanita hamil dan menyusui, menderita DM tipe 2 (GDS $\geq 200)$ yang ditentukan melalui pemeriksaan kadar glukosa sewaktu, individu dalam tahap terapi obat thiazolidinedione (TZD), obat anti diabetes, obat golongan glukokortikoid (misal dexamethasone) yang diketahui melalui pengisian data diri, subyek yang mengalami gastritis atau masalah pencernaan selama proses pemberian treatment, dan subyek yang tidak dapat mengikuti proses penelitian hingga akhir, tidak diikutsertakan dalam data penelitian. Subyek penelitian yang telah bersedia mengikuti penelitian melalui penandatangan lembar informed consent selanjutnya diukur IMT dan rasio lingkar pinggang dan pinggulnya untuk 
Jurnal Care Vol .5, No.2,Tahun 2017

digolongkan dalam kelompok obesitas atau kelompok IMT normal. Penentuan IMT dilakukan dengan mengukur berat dan tinggi badan subyek tanpa menggunakan sepatu dan subyek diusahakan menggunakan baju yang tipis. Pengukuran lingkar pinggang dan panggul menggunakan meteran jahit. Lingkar pinggang diukur di daerah sekitar pusar dengan mengambil area tersempit sedangkan lingkar pinggul diukur di daerah pelvis dengan mengambil area terluas. Setelah itu, dilakukan pengukuran kadar gula darah sewaktu (GDS) sebagai tahapan screening subyek yang mungkin memiliki kadar GDS lebih dari normal.

Subyek diminta mengkonsumsi teh hijau kemasan sehari dua kali yaitu saat pagi dan sore hari selama 30 hari. Konsumsi teh dilakukan satu jam sebelum atau sesudah makan. Teh yang diberikan kepada subyek berupa teh celup kemasan dengan netto $2 \mathrm{~g}$ per kantong. Teh celup ini kemudian diseduh dengan air panas sebanyak $150 \mathrm{ml}$ selama kurang lebih 3 menit. Subyek tidak diperkenankan menambahkan gula pada hasil seduhan teh. Pengukuran antropometri selanjutnya dilakukan setiap seminggu sekali selama empat minggu.

Data yang diperoleh diuji normalitasya menggunakan uji Kolmogorov-Smirnov.
Perbedaan karakteristik subyek penelitian antara kelompok obesitas dan kelompok dengan IMT normal diuji menggunakan uji t tidak berpasangan. Rerata Indeks Massa Tubuh (IMT) dan rasio lingkar pinggang dan panggul awal dan akhir pada kelompok obesitas dan kelompok IMT dan normal diuji menggunakan uji $\mathrm{t}$ berpasangan. Hubungan antara konsumsi teh hijau terhadap IMT dan rasio lingkar pinggang dan panggul pada kedua kelompok dianalisis menggunakan uji korelasi Pearson.

\section{HASIL}

\section{Karakteristik Subyek Penelitian}

Berdasarkan Tabel 1 diketahui bahwa seluruh subyek penelitian memiliki kadar gula darah sewaktu (GDS) normal dan kadar ini tidak berbeda signifikan antara kelompok obesitas dan kontrol. Perbedaan signifikan pada kedua kelompok tersebut tampak pada nilai berat badan awal dan indeks massa tubuh (IMT) awal yang memang menjadi pembeda kedua kelompok, tinggi badan, dan lingkar pinggang dan panggul awal. Tetapi, rasio lingkar pinggang dan panggul tidak menunjukkan adanya perbedaan signifikan antara kedua kelompok. 
Tabel 1. Karakteristik Subyek Penelitian di Fakultas Ilmu Kesehatan Program Studi Ilmu Keperawatan Universitas Tribhuwana Tunggadewi Malang

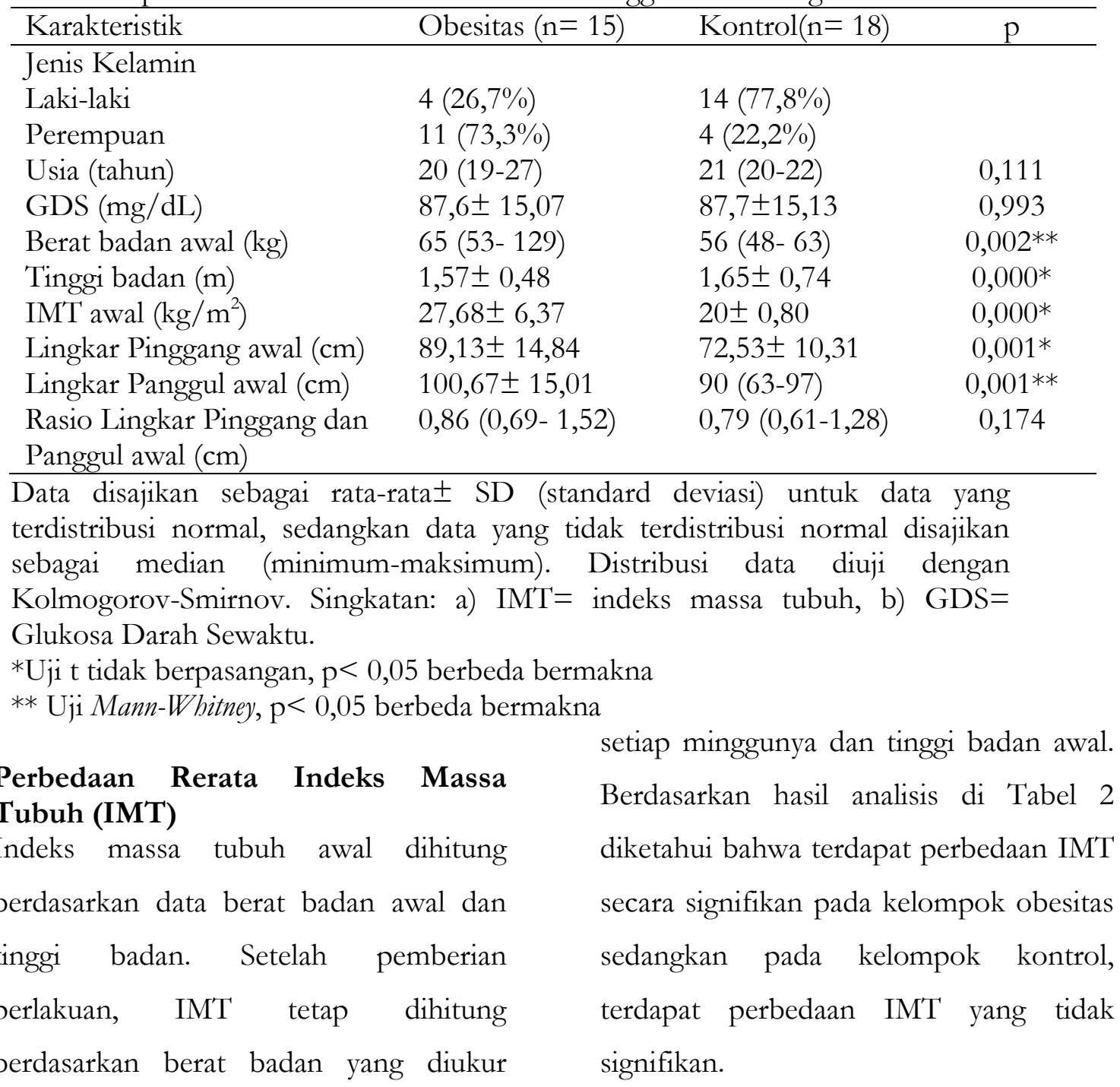

Tabel 2. Perbedaan Indeks Massa Tubuh (IMT) Sebelum dan Setelah Pemberian Teh Hijau Fakultas Ilmu Kesehatan Program Studi Ilmu Keperawatan Universitas Tribhuwana Tunggadewi Malang

\begin{tabular}{llll}
\hline Kelompok & IMT Awal & Rata- rata IMT Akhir & $\mathrm{P}$ \\
\hline Obesitas $(\mathrm{n}=15)$ & $27,68 \pm 6,37$ & $27,01 \pm 5,74$ & $0,004^{*}$ \\
Kontrol $(\mathrm{n}=18)$ & $20,08 \pm 0,85$ & $19,99 \pm 0,94$ & 0,238 \\
\hline Data disajikan sebagai & rata-rata \pm SD (standard deviasi) untuk data yang \\
terdistribusi normal. Distribusi data diuji & dengan & Kolmogorov-Smirnov. \\
Singkatan: a) IMT $=$ indeks massa tubuh. & & \\
$*$ Uji t berpasangan, $\mathrm{p}<0,05$ berbeda bermakna
\end{tabular}

\section{Perbedaan Rerata Rasio Lingkar Pinggang dan Panggul}

Rerata rasio lingkar pinggang dan panggul dihitung dengan membandingkan lingkar pinggang dan lingkar panggul. Rasio ini dihitung sebelum dan sesudah pemberian perlakuan yang dihitung setiap minggu. 
Berdasarkan hasil analisis statistik yang tersaji pada Tabel 1, tidak ada perbedaan signifikan antara rasio lingkar pinggang dan panggul awal dan akhir, baik di kelompok obesitas maupun kelompok kontrol. Bila ditinjau kembali pada Tabel 3, rasio lingkar pinggang dan panggul antara kelompok obesitas dan kontrol juga tidak berbeda signifikan.

Tabel 3. Perbedaan Rasio Lingkar Pinggang dan Panggul Sebelum dan Setelah Pemberian Teh Hijau

\begin{tabular}{rccc}
\hline Kelompok & Rasio Awal & Rasio Akhir & $\mathrm{P}$ \\
\hline Obesitas $(\mathrm{n}=15)$ & $0,86(0,69-1,52)$ & $0,85(0,70-1,52)$ & 0,916 \\
Kontrol $(\mathrm{n}=18)$ & $0,79(0,61-1,28)$ & $0,80(0,60-1,34)$ & 0,744 \\
\hline
\end{tabular}

Data disajikan sebagai rata-rata \pm SD (standard deviasi) untuk data yang terdistribusi normal. Distribusi data diuji dengan Kolmogorov-Smirnov. Singkatan:

a) IMT $=$ indeks massa tubuh.

$*$ Uji t berpasangan, $\mathrm{p}<0,05$ berbeda bermakna

\section{Pengaruh Konsumsi Teh Hijau Terhadap IMT dan Rasio Lingkar Pinggang dan Panggul}

Hubungan antara konsumsi teh hijau terhadap IMT dan rasio lingkar pinggang dan panggul pada kedua kelompok dianalisis menggunakan uji korelasi Pearson. Hasil uji korelasi menunjukkan bahwa tidak terdapat hubungan antara konsumsi teh hijau dengan IMT dan rasio lingkar pinggang dan panggul (Tabel 4). Hal ini menunjukkan bahwa perubahan IMT dan rasio lingkar pinggang dan panggul pada studi ini tidak dipengaruhi oleh konsumsi teh hijau.

Tabel 4. Hubungan Konsumsi Teh Hijau dengan IMT dan Rasio Lingkar Pinggang dan Panggul

\begin{tabular}{ccccc}
\hline Variabel Independen & Variabel Dependen & Kelompok & Pearson Corr & $\mathrm{p}$ \\
\hline \multirow{2}{*}{$\begin{array}{c}\text { Konsumsi Teh Hijau } \\
\text { (minggu) }\end{array}$} & \multirow{2}{*}{ IMT } & Obesitas & $-0,048$ & 0,715 \\
& \multirow{2}{*}{ Rasio } & Kontrol & $-0,086$ & 0,472 \\
& & Obesitas & 0,008 & 0,949 \\
& & Kontrol & 0,006 & 0,959 \\
\hline
\end{tabular}

\section{PEMBAHASAN}

Penelitian yang bertujuan untuk mengeksplorasi bahan alam yang dapat dijadikan sebagai treatment obesitas mulai sering dikaji secara intensif, salah satunya yaitu teh hijau. Teh hijau memberikan efek positif terhadap penurunan penanda obesitas baik secara in vitro (Cunha et al., 2013) maupun in vivo (Wu et al., 2003). Penelitian ini menggunakan teh hijau sebagai intervensi diet pada kelompok obesitas maupun kelompok dengan 
Indeks Massa Tubuh (IMT) normal. Desain dua kelompok tersebut dibuat untuk mengetahui pengaruh konsumsi teh hijau bagi orang obesitas dan orang dengan IMT normal.

Seluruh subyek penelitian dipastikan tidak memiliki masalah metabolisme glukosa melalui screening awal pemeriksaan Gula Darah Sewaktu (GDS). Hasil uji beda antara rerata IMT sebelum mengkonsumsi teh hijau dengan setelah mengkonsumsi teh hijau menunjukkan perbedaan yang signifikan pada kelompok obesitas, sedangkan pada kelompok kontrol menunjukkan tidak adanya perbedaan signifikan. Adanya penurunan IMT secara signifikan pada kelompok obesitas sesuai dengan beberapa hasil penelitian sebelumnya yang menunjukkan adanya efek anti obesitas teh hijau.

Epigallocatechin gallate (EGCG) merupakan kandungan katekin terbesar di dalam teh hijau yang diketahui memiliki efek baik bagi kesehatan. EGCG menghambat proliferasi sel adiposa dan diferensiasi pada sel 3T3-L1, meningkatkan oksidasi lemak, meningkatkan penggunaan energi (Kim \& Kim, 2013). Selain mekanisme tersebut, jalur yang memungkinkan efek anti obesitas teh hijau yaitu melalui peningkatan produksi adiponektin pada tikus. Adiponektin diketahui memiliki efek antagonis dengan biomarker obesitas, melalui jalur inhibisi Erk, peningkatan proliferasi peroxisome proliferator-activated receptor $\gamma$ (PPAR $\gamma)$, dan peningkatan ekspresi PPAR $\gamma$ (Tian et al., 2013).

Hasil analisis menunjukkan tidak adanya perbedaan signifikan rasio lingkar pinggang dan panggul baik sebelum konsumsi teh hijau maupun setelah konsumsi teh hijau, pada kelompok obesitas maupun kelompok kontrol. Data karakteristik awal subyek juga tidak menunjukkan perbedaan signifikan rasio lingkar pinggang dan panggul antara kelompok obesitas dan kelompok kontrol. Rasio lingkar pinggang dan panggul merupakan parameter untuk mengukur obesitas abdominal sedangkan IMT merupakan parameter utama dalam mengukur obesitas tanpa bisa membedakan distribusi lemak.

Menurut Stevens et al. (2008), perubahan IMT tidak berkaitan dengan perubahan rasio lingkar pinggang dan panggul sehingga meskipun pada penelitian ini terdapat perbedaan IMT secara signifikan antara kelompok obesitas dan kelompok kontrol serta terjadi perbedaan signifikan antara IMT sebelum dan sesudah mengkonsumsi teh hijau, hal tersebut 
tidak berkaitan dengan perubahan rasio lingkar pinggang dan panggul. Selain itu, ada variabel lain yang diduga berpengaruh dalam perubahan parameter obesitas yaitu usia. Semakin bertambah usia seseorang, maka rasio lingkar pinggang dan panggul juga bertambah (Stevens et al., 2008). Sebagian besar subyek penelitian berusia sekitar 20 tahun dengan aktivitas yang hampir sama sebagai mahasiswa sehingga hal ini memungkinkan tidak munculnya perbedaan rasio lingkar pinggang dan panggul.

Hasil analisis uji korelasi dalam penelitian dilakukan untuk mengetahui lebih lanjut tentang kekuatan hubungan antara konsumsi teh hijau dengan IMT dan rasio lingkar pinggang dan panggul. Hal ini dilakukan untuk menunjukkan bahwa konsumsi teh hijau merupakan determinan utama dalam perubahan Indeks Massa Tubuh (IMT) dan rasio lingkar pinggang dan panggul. Hasil uji korelasi Pearson menunjukkan tidak adanya korelasi antara konsumsi teh hijau dengan IMT dan rasio lingkar pinggang dan panggul. Hal ini berarti bahwa konsumsi teh hijau bukan merupakan determinan utama dalam perubahan IMT khususnya pada kelompok obesitas.
Pada pengukuran obesitas, terdapat beberapa variabel lain yang juga menjadi determinan kuat dalam penentuan IMT, presentase lemak tubuh, total adiposit maupun distribusi lemak. Berbagai variabel tersebut antara lain jenis kelamin, usia, aktivitas fisik, kebiasaan merokok, kebiasaan minum alkohol, frekuensi konsumsi kopi, jenis makanan yang dikonsumsi, dan ras (Wu et al., 2003). Penelitian ini tidak mampu mengontrol seluruh variabel determinan tersebut sehingga konsumsi teh hijau bukan merupakan satu- satunya faktor determinan dalam perbedaan Indeks Massa Tubuh (IMT) sebelum dan setelah mengkonsumsi teh hijau. Selain itu, pelaksanaan penelitian yang selesai seminggu lebih awal karena sebagian besar subyek penelitian tidak dapat mengikuti prosedur penelitian diduga sebagai faktor yang membuat konsumsi teh hijau bukan sebagai determinan yang kuat. Penelitian menggunakan teh hijau pada manusia sebagian besar merupakan penelitian dengan penelitian kobort yang membutuhkan waktu lama mengingat efek fisiologis yang tidak langsung muncul. Penelitian menggunakan teh hijau pada manusia dengan hasil signifikan berupa penurunan Gula Darah Post Prandial (GDPP) setelah pemberian teh hijau dengan dosis tinggi dilaksanakan 
selama minimal satu bulan (Lahirin et al., 2015).

\section{KESIMPULAN}

Konsumsi teh hijau menyebabkan penurunan rerata IMT secara signifikan pada kelompok subyek obesitas, tetapi tidak menyebabkan adanya perberdaan rerata rasio lingkar pinggang dan panggul secara signifikan baik pada kelompok obesitas maupun kelompok kontrol. Pada penelitian ini, konsumsi teh hijau bukan merupakan determinan utama dalam menentukan perubahan IMT dan rasio lingkar pinggang dan panggul.

\section{UCAPAN TERIMA KASIH}

Peneliti sampaikan terima kasih yang mendalam kepada pihak Universitas Tribhuwana Tunggadewi selaku pihak pemberi dana utama pada penelitian ini melalui skema Penelitian Hibah Unitri (PHU) 2016. Selain itu, peneliti juga berterima kasih kepada seluruh partisipan penelitian yang telah bekerja sama untuk secara aktif menjadi bagian dari penelitian ini.

\section{REFERENSI}

Badan Penelitian dan Pengembangan Kesehatan Kemenkes RI. (2013). Riset Kesehatan Dasar. Jakarta.
Cunha, C.A., Lira, F.S., Neto, J.C.R., Pimentel, G.D., Souza, G.H.I et al. (2013). Green Tea Extract Supplementation Induces the Lipolytic Pathway, Attenuates Obesity, and Reduces Low- Grade Inflammation in Mice Fed a HighFat Diet. Mediators of Inflammation, 18.

Cyboran,S., Strugala, P., Wloch, A., Oszmianski, J., Kleszczynska, H. (2015). Concentrated Green Tea Supplement: Biological Activity and Molecular Mechanism. Life Sciences, 126: $1-9$.

Ellulu, M., Abed, Y., Rahmat, A., Ranneh, Y., Ali, Faisal. (2014). Epidemiology of obesity in developing countries: challenges and prevention. $H O A J: 1-6$.

Khan, N \& Mukhtar, H. (2013). Tea and Health: Studies in Humans. Curr Pharm, 19(34): 6141-6147.

Kim, H.M., Kim, J. (2013). The Effects of Green Tea on Obesity and Type 2 Diabetes. Diabetes and Metabolism Journal, 37: 173- 175.

Lahirin, R., Permadhi, I., Mudjihartini, N., Rahmawati, R., Sugianto, R. (2015). Additional Benefit Of Higher Dose Green Tea In 
Lowering Postprandial Blood Glucose. Medical Journal of Indonesia, 24(2): 97- 102.

Ng, Marie., Fleming, T., Robinson, M., Thomson, B., Graetz, N., Margono, C et al. 2014. Global, regional, and national prevalence of overweight and obesity in children and adults during 1980-2013: a systematic analysis for the Global Burden of Disease Study 2013. Lancet, 384: 766-781.

Roemling, C., \& Qaim, M. 2012. Obesity trends and determinants in Indonesia. Appetite, 58: 1005-1013.

Sae-tan, S., Grove, K.A., Lambert, J.D. 2011. Weight Control and Prevention of Metabolic Syndrome by Green Tea. Pharmacological Research, 64: 146-154.
Stevens, J., McClain, J.E., Truesdale, K.P. (2008). Selection Measure in Epidemiologic Studies of the Consequences of Obesity. Int $J$ Obes, 32: 560-566.

Tian C., Ye X., Zhang R., Long J., Ren W., Ding S., et al. (2013). Green tea polyphenols reduced fat deposits in high fat-fed rats via erk1/2PPARgamma-adiponectin pathway. PLoS One,8:e53796.

Wolfram, S., Wang, Y., Thielecke, F. (2006). Anti-obesity effects of green tea: From Bedside to Bench. Mol Nutr Food Res, 50: 176-187.

Wu, C., Lu, F., Chang, C., Chang T., Wang, R., Chang, C. (2003). Relation among Habitual Tea Consumption, Percent Body Fat, and Body Fat Distribution. Obesity Research, 11(9): 1088- 1095. 